In regard to this last point, Mrs. Nice makes it clear that every individual male song-sparrow has his own repertoire of songs, all of them readily distinguishable, with a little practice, from those of all other males. The number of separate songs in a cock bird's repertoire varies from six to twentyfour. One male song-sparrow sang from 4.45 a.m. to 7.43 p.m., giving 2,305 songs in fifteen hours, with 278 songs as his highest rate per hour !

Again (as Lack has since shown in the English robin) migration is a matter of individual variation; and indeed birds that migrate one year need not do so the next.

There are a few criticisms to be made. Among several misprints (including some, such as the transposition of lines on p. 64, which one does not expect to find in a scientific publication), there is one serious one in Table 13 where songs should apparently be song-series ; and in Table 5, the "group V" discussed in the text is omitted. Although a great volume of literature is comparatively reviewed, there are some curious and unexplained gaps. Thus, though Lloyd Morgan's fundamentel "Habit and Instinct" and Kirkman's recent important studies on egg and nestsite recognition are cited in the literature list, they appear to be neglected in the discussion. The important work of Lockley on homing and other activities in shearwaters is entirely omitted, together with the numerous data of various authors on the behaviour of the gannet, and the valuable work of Nicholson and Koch, complete with gramophone records, on the song of British birds. More generally, the sections on courtship and display might have been fuller, with more weight given to studies on other forms, notably non-passerines.

These, however, are mere minor omissions. The work as a whole is a monument of industry and a model of method. If the author appears to go a little far in claiming (p. 273) that "the study of animal behavior is the only and ultimate souree of understanding ourselves", it is certainly true that it is an indispensable aid in that task, and further that it reveals unexpected aspects of mental evolution which even the most complete study of our own psychological organization could not have made available. In any event, in this and tha preceding work, Mrs. Nice has made a massive and outstanding contribution to our advaneing knowledge of animal behaviour. Julian Huxidey.

\section{OX BLOOD FOR BLOOD TRANSFUSION}

$\mathrm{M}$ ANY people must have wondered whether some use could not be made of the large quantities of ox blood available in our slaughter-houses. If the conclusions drawn by Dr. Edwards (Brit. Med. $J$. Jan. 15, 1944) and his collaborators survive the further tests to which they are being subjected, the ax of the future may not only give his life and meat for man, but may serve him also with his very blood and may be kept for that parpose by the com. munity.

The use of plasma for surgical treatment is, as Dr. Edwards points out, inereasing rapidly, and the search for a suitable plasma other than that provided by the blood banks is in progress. It would seem that the collaboration between Dr. Edwards and the Regional Transfusion Laboratories, the North Staf- fordshire Royal Infirmary and experts at Cambridge and Liverpool, has gone a long way towards the solution of this problem. The substitutes for human plasma which have been tried have not, Dr. Edwards states, possessed the three characteristics that are necessary, namely, that they should be retained in the circulation and should eventually be metabolized, that they should exert an osmotic pressure equivalent to that of the plasma and that they should be nontoxic, free from antibodies and non-antigenic. Bayliss in 1916 tried 6 per cent gum acacia in saline for the treatment of shock, but this was only partially metabolized and much of it remained in the tissues with unpleasant consequences. Other substances mentioned by Dr. Edwards may maintain the blood. pressure in shock and hæmorrhage, but they do not restore the blood protein. Animal plasma protein most nearly resembles human plasma protein, and the total protein of bovine blood most nearly approaches that of human blood; but it contains a much higher percentage of fibrinogen. Further, its albumin/globulin ratio is lower, so that bovine blood might exert a lower osmotic pressure, because the albumin fraction exerts the greater pressure. Bovine blood is, however, available in practically unlimited quantities.

It has been shown that crude bovine serum is unsuitable. Dr. Edwards outlines the attempts to overcome such difficulties as the serum sickness which it causes and the tendency to hæmolysis of the human red cells and the slow rate of administration. $\mathrm{He}$ explains in detail the method which he and his collaborators have finally adopted for the preparation of a bovine serum which has been tested on twenty-six cases. The method includes the heating of the serum to $72^{\circ} \mathrm{C}$. to destroy the antibodies and the addition of 0.2 per cent of formalin and ammonia to render the proteins uncoagulable. He claims that the serum obtained fulfils the requirernents indicated above.

The final product is called D.B.S. (despeciated bovine serum). It has an osmotic pressure comparable to that of filtered human plasma. It was kept for six months in Dr. Edwards's car and was then given to a patient without untoward results; after nine months in a refrigerator it had not deteriorated. It can, moreover, be given very rapidly and in large amounts. After a preliminary trial on twenty-six patients, Dr. Edwards clairns that it is safe to give it to man and that it is well retained in the circulation. It is easily prepared in large quantities.

The possibility of the transmission by it of tuber culosis or of Brucella abortus has been considered. Dr. Edwards advocates bleeding from tubereulintested stock only; or only from bullocks and heifers, because only 6 per cent of these coming to the slaughter-house are infected with tuberculosis or Brucella abortus, whereas the rate among slaughtered cows is 30 per cent. If the meat inspector reports gross tubereulous infection of the carcass, the blood taken from that animal should be discarded. But the Seitz filtration during the process of manufacture should, Dr. Edwards thinks, remove any of these organisms that may be present in the blood.

Before he gives a final judgment, Dr. Edwards wisely awaits the results of more detailed hrematological and biochemical work on the effects of the administration of despeciated blood serum to patients in states of shock, hypoproteinæmia and protein deprivation and loss. G. LAPAGE. 